\title{
Coincidental light chain induced proximal tubulopathy with lupus nephritis: a case report and review of the literature
}

\author{
Wael Mostafa Hamza * ${ }^{*}$ and Ahmed Mohammed AlEssa
}

\begin{abstract}
Background: We report a case of light chain proximal tubulopathy associated with lupus nephritis in a patient known to have systemic lupus erythematosus. The kidney can be injured in several ways in any of these disorders. Light chain proximal tubulopathy is a rare form of renal tubular injury that may occur in and complicate plasma cell dyscrasia, characterized by cytoplasmic inclusions of the monoclonal light chain within proximal tubular cells. Lupus nephritis is a common form of renal injury as it occurs in about $25-50 \%$ of adult patients with systemic lupus erythematosus.

Case presentation: We present a 57-year-old African patient known to have systemic lupus erythematosus and hypertension presented with a new complaint of microscopic hematuria. A renal biopsy was performed and revealed lupus nephritis class II concurrently associated with light chain induced proximal tubulopathy. A subsequent bone marrow biopsy was performed, which revealed multiple myeloma.

Conclusions: We report a case of coincidental lupus nephritis and proximal tubulopathy featuring a combined constellation of rare histopathological features that might add to the relationship between systemic lupus and paraproteinemia.
\end{abstract}

Keywords: Proximal tubulopathy, Lupus nephritis, Plasma cell dyscrasia, Paraproteinemia, Free light chain

\section{Introduction}

Plasma cell dyscrasia (PCD) refers to a spectrum of several disorders characterized by monoclonal paraprotein production, with a wide variety of clinical presentations and outcomes [1]. The renal involvement in PCD is a common finding as it is present in up to half of myeloma patients at presentation [2]. Renal insufficiency is a defining event in patients with multiple myeloma. Myeloma cast nephropathy is the most common presentation or histologic finding and the second most common cause of death in these patients [1, 3]. Many studies have

${ }^{*}$ Correspondence: wmmostafa@iau.edu.sa

Department of Pathology and Laboratory Medicine, College of Medicine, King Fahd Hospital of the University, Imam Abdulrahman Bin Faisal

University, Dammam, Saudi Arabia described renal lesions associated with PCD in detail $[2,4]$. The renal involvement in multiple myeloma and related disorders is multifactorial, including indirectly through the effect of paraproteins over the glomeruli (light chain deposition disease), the proximal tubules (proximal tubulopathy), the distal tubules (myeloma cast nephropathy), and the renal vasculature (light chain amyloidosis), or rarely directly through the infiltration of the renal parenchyma by the neoplastic plasma cells. In patients with multiple myeloma, myeloma cast nephropathy most commonly represents lesion (approximately 30\%) [3].

Light chain proximal tubulopathy (LCPT) is characterized by cytoplasmic monoclonal light chain inclusions within proximal tubular cells [5]. The structure of these inclusions had been categorized as crystalline and original author(s) and the source, provide a link to the Creative Commons licence, and indicate if changes were made. The images or other third party material in this article are included in the article's Creative Commons licence, unless indicated otherwise in a credit line to the material. If material is not included in the article's Creative Commons licence and your intended use is not permitted by statutory regulation or exceeds the permitted use, you will need to obtain permission directly from the copyright holder. To view a copy of this licence, visit http://creativecommons.org/licenses/by/4.0/. The Creative Commons Public Domain Dedication waiver (http://creativeco mmons.org/publicdomain/zero/1.0/) applies to the data made available in this article, unless otherwise stated in a credit line to the data. 
noncrystalline. However, the importance of this categorization and the treatment effect is unknown for these cases. The most important predictor of the disease progression is the early detection and the aggressiveness of treating the underlying etiology in some instances [5]. A review of the literature reveals 43 cases of light chain proximal tubulopathy with a presentation similar to our case. The kidney is commonly affected in a patient with systemic lupus erythematosus (SLE) as it occurs in approximately $25-50 \%$ of adult patients with systemic lupus [6] with different histopathological patterns and clinical manifestations. The involvement could be in the form of podocytopathy [7] or have one of the typical forms of lupus nephritis classes [8]. The coexistence of PCD or paraproteinemia in SLE patients has been described in the literature in very few cases with enigmatic pathogenesis and unsettled clinical features $[9,10]$. On the other hand, patients with plasma cell dyscrasia might have autoimmune manifestations [11]. We report a case of coincidental lupus nephritis and LCPT. To the best of our knowledge, this is the first case to be reported.

\section{Case presentation Clinical data}

A 57-year-old African patient was known to have SLE (diagnosed at the age of 27 years) and hypertension (diagnosed at the age of 52 years); both diseases were under control according to the patient's provided history. The patient had been doing fine for the past 5 years and recently presented to the nephrology clinic at our hospital with new-onset microscopic hematuria. There is no known family history of SLE or other autoimmune diseases, or previous history of renal disease manifestations. Drug list at the time of presentation: tacrolimus $4 \mathrm{mg}$ daily, prednisolone $15 \mathrm{mg}$ daily, amlodipine $5 \mathrm{mg}$ daily, valsartan $80 \mathrm{mg}$ daily, nifedipine $20 \mathrm{mg}$ daily, pantoprazole $40 \mathrm{mg}$ daily, vitamin D3 1000 unit capsule daily, calcium carbonate $1500 \mathrm{mg}$ daily, and Vitamin B complex one tablet daily. No definite data are available on the compliance of the patient with the reported medications as the patient was initially diagnosed for SLE and hypertension elsewhere. During the follow-up in our hospital (last 7 years), the patient was apparently compliant with regular filling of medications every 3 months. The laboratory findings and urine analysis at the time of presentation are listed in Tables 1 and 2, respectively.

A renal biopsy was performed.

\section{Histopathological examination}

The light microscopic examination of the specimen revealed cores of renal corticomedullary tissue. Thirtyseven glomeruli were identified. The tufts show a mesangioproliferative pattern (Fig. 1A). The proximal tubular
Table 1 Laboratory findings at the time of presentation

\begin{tabular}{lll}
\hline Laboratory test & Result & Reference range \\
\hline White blood cells & $7.2 \times 10^{3} / \mu \mathrm{L}$ & $4.0-11.0 \times 10^{3} / \mu \mathrm{L}$ \\
Red blood cells & $3.8 \times 10^{6} / \mu \mathrm{L}$ & $4.2-5.5 \times 10^{6} / \mu \mathrm{L}$ \\
Hemoglobin & $9.4 \mathrm{~g} / \mathrm{dl}$ & $(12-16 \mathrm{~g} / \mathrm{dl})$ \\
Hematocrit & $29.2 \%$ & $(37-47 \%)$ \\
Mean corpuscular volume & $76.9 \mathrm{fl}$ & $(80-94 \mathrm{fl})$ \\
Mean corpuscular hemo- & $24.9 \mathrm{pg}$ & $(27-32 \mathrm{pg})$ \\
$\quad$ globin & & \\
Mean corpuscular hemo- & $32.3 \mathrm{~g} / \mathrm{dL}$ & $(32-36 \mathrm{~g} / \mathrm{dl})$ \\
$\quad$ globin concentration & & \\
Serum creatinine level & $1.23 \mathrm{mg} / \mathrm{dl}$ & $(0.6-1.0 \mathrm{mg} / \mathrm{dl})$ \\
Blood urea nitrogen & $19 \mathrm{mg} / \mathrm{dl}$ & $(7-18 \mathrm{mg} / \mathrm{dl})$ \\
Urine protein & $53 \mathrm{mg} / \mathrm{dL}$ (of tubular & $(\leq 11.9 \mathrm{mg} / \mathrm{dl})$ \\
& and glomerular & \\
24-hour urine protein & $898 \mathrm{mg} / 24$ hours & $(50-80 \mathrm{mg} / 24 \mathrm{hours})$ \\
Sodium & $136 \mathrm{mEq} / \mathrm{L}$ & $(136-145 \mathrm{mEq} / \mathrm{L})$ \\
Potassium & $4.80 \mathrm{mEq} / \mathrm{L}$ & $(3.5-5.1 \mathrm{mEq} / \mathrm{L})$ \\
Chloride & $103 \mathrm{mEq} / \mathrm{L}$ & $(98-107 \mathrm{mEq} / \mathrm{L})$ \\
Serum albumin & $2.9 \mathrm{~g} / \mathrm{dl}$ & $(3.4-5.0 \mathrm{~g} / \mathrm{dl})$ \\
Total bilirubin & $0.3 \mathrm{mg} / \mathrm{dl}$ & $(0.2-1.2 \mathrm{mg} / \mathrm{dl})$ \\
Direct bilirubin & $<0.05 \mathrm{mg} / \mathrm{dL}$ & $(0.05-0.2 \mathrm{mg} / \mathrm{dl})$ \\
Erythrocyte sedimenta- & $89 \mathrm{~mm} / \mathrm{hour}$ & $(0-20 \mathrm{~mm} / \mathrm{hour})$ \\
tion rate & & \\
C3 complement & $147 \mathrm{mg} / \mathrm{dL}$ & $(90-180 \mathrm{mg} / \mathrm{dl})$ \\
C4 complement & $14 \mathrm{mg} / \mathrm{dL}$ & $(10-40 \mathrm{mg} / \mathrm{dl})$ \\
C-reactive protein & $0.30 \mathrm{mg} / \mathrm{dL}$ & $(0.05-0.3 \mathrm{mg} / \mathrm{dl})$ \\
\hline
\end{tabular}

segments showed prominent cytoplasmic textured inclusions (Fig. 2); a single Congo red positive cast was detected (Fig. 3A). The interstitium shows patchy mononuclear predominantly plasmacytic infiltrate associated with edema and minimal loose fibrosis. Focal minimal interstitial deposit of amyloid material was detected. The arteries showed moderate-to-marked intimal fibroplasia and focal deposit of amyloid material (Fig. 3B). The arterioles showed focal mild hyalinosis.

Immunohistochemical staining by immunofluorescence (IF): two glomeruli presented in the IF submitted sample showed glomerular mesangial deposits for IgG (score 2+) and IgA (score 1+) (Fig. 1B, C). No immune deposits for IgM, C3, or C1q were revealed.

By immunoperoxidase technique (IP) (Fig. 4): the kappa light chain stain showed strong cytoplasmic positivity within proximal tubular segments and aggregates of plasma cells. The lambda light chain stain showed weak focal positivity.

Electron microscopy (EM) specimen was composed of fibrous tissue and skeletal muscle fibers. 
Table 2 Urine analysis result at time of presentation

\begin{tabular}{|c|c|c|}
\hline Test & Result & Reference range \\
\hline Color & Yellow & - \\
\hline Clarity & Light turbid & - \\
\hline Glucose & Negative & Negative \\
\hline Bilirubin & Negative & Negative \\
\hline Ketone & Negative & Negative \\
\hline Specific gravity & 1.019 & $\begin{array}{l}(1.00-1.030 \\
1.010 \text { to } \geq 1.030)\end{array}$ \\
\hline Blood & Present (small amount) & Negative \\
\hline $\mathrm{pH}$ & 5 & $(5.5-6.0)$ \\
\hline Protein & $15 \mathrm{mg} / \mathrm{dl}$ & Negative \\
\hline Urobilinogen & Negative & $(0.2-1.0)$ \\
\hline Nitrate & Negative & Negative \\
\hline Leukocytes & Large & Negative \\
\hline White blood cell & $>200$ & 0-2/high-power field \\
\hline Red blood cell & $2-5$ & 0-3 /high-power field \\
\hline Cast & None seen & Negative \\
\hline Epithelial cells & Rare & (None-Rare) \\
\hline Necrotic epithelial cells & None seen & None \\
\hline Yeast cells & None seen & None \\
\hline Mucus threads & None seen & None to rare \\
\hline Trichomonas & None seen & None \\
\hline Bacteria & +1 & None to rare \\
\hline Spermatozoa & None seen & None \\
\hline Schistosoma & None seen & None \\
\hline
\end{tabular}

A diagnosis of lupus nephritis class (IIa), associated with light chain induced proximal tubulopathy, minimal interstitial and vascular amyloidal deposits, and hypertensive renovascular changes was made.

\section{Further action}

The clinician decided to perform serum protein electrophoresis. The results are presented in Table 3.

The 24-h Bence Jones protein analysis result was positive for Bence Jones protein, and the Bence Jones protein type was free kappa light chain. Bone marrow biopsy was subsequently performed and revealed hypercellular marrow showing aggregates of closely packed monoclonal plasma cells comprising more than $15 \%$ of the marrow cellularity.

The patient was advised to seek medical advice at another center for further radiological workup and treatment owing to unavailability of specified drugs at our hospital.

\section{Discussion}

The renal pathology in PCD has several faces of involvement with different patterns and nephron topographic affection via free light chains. The tubular loop of the nephron is variably affected depending on whether the free light chains exert epithelial injury and where these light chains wield their effect (that is, proximal and distal tubulopathy). Interestingly, cases were reported involving both proximal and distal tubules [12,13], and moreover, others recently described an associated glomerular tuft involvement $[14,15]$.

LCPT is relatively the latest tubular pattern described in this category, results from the accumulation of free light chains within the proximal tubular epithelia, and presents a diagnostic challenge not to be overlooked during daily practice. The accumulated inclusions are reported to be crystalline or noncrystalline and occasionally Congo red positive [16].

While the light microscopic pattern in our case was textured fibrilloid inclusions, in contrast to the variable light microscopic patterns that are described in the literature, including vacuolization with eosinophilic granules [14], small round amorphous intracytoplasmic bodies [16], osmotic diuresis like pattern [17], and marked vacuolization with the formation of apical blebs [18].

In this report, we used the immunoperoxidase technique on paraffin-embedded tissue to detect the light chains, with very satisfactory results. In most of the reported cases, the used technique is immunofluorescence, while immunoperoxidase $[19,20]$ and immunoelectron techniques $[14,17]$ are less frequently used for this purpose. Both kappa $[14,15,17,19]$ and lambda free light chains $[12,13,16,18]$ are described.

This case is unique in that there is infiltration of the kidney by monoclonal plasma cells, which is an exceedingly rare lesion to be detected in cases of multiple myeloma [21], whether associated with indirect nephropathic effect or not. Moreover, to the best of our knowledge, the detection of Mott cells described in this report is the first in the literature.

Another important feature, in this case, is the presence of a Congo red positive cast, a feature that could be rarely seen with cast nephropathy and not reported with LCPT, to our knowledge. Furthermore, we had vascular and focal interstitial amyloidal deposits in our biopsy that could be intuitively free light chain-induced or related to the chronicity of the autoimmune disease the patient had (a matter unsolved by immunostains owing to specimen limitation).

In our patient, plasma cell myeloma was confirmed by bone marrow biopsy results fulfilling the International Myeloma Working Group criteria (serum monoclonal protein $\geq 3 \mathrm{~g} / \mathrm{dL}$ with positive urinary monoclonal 

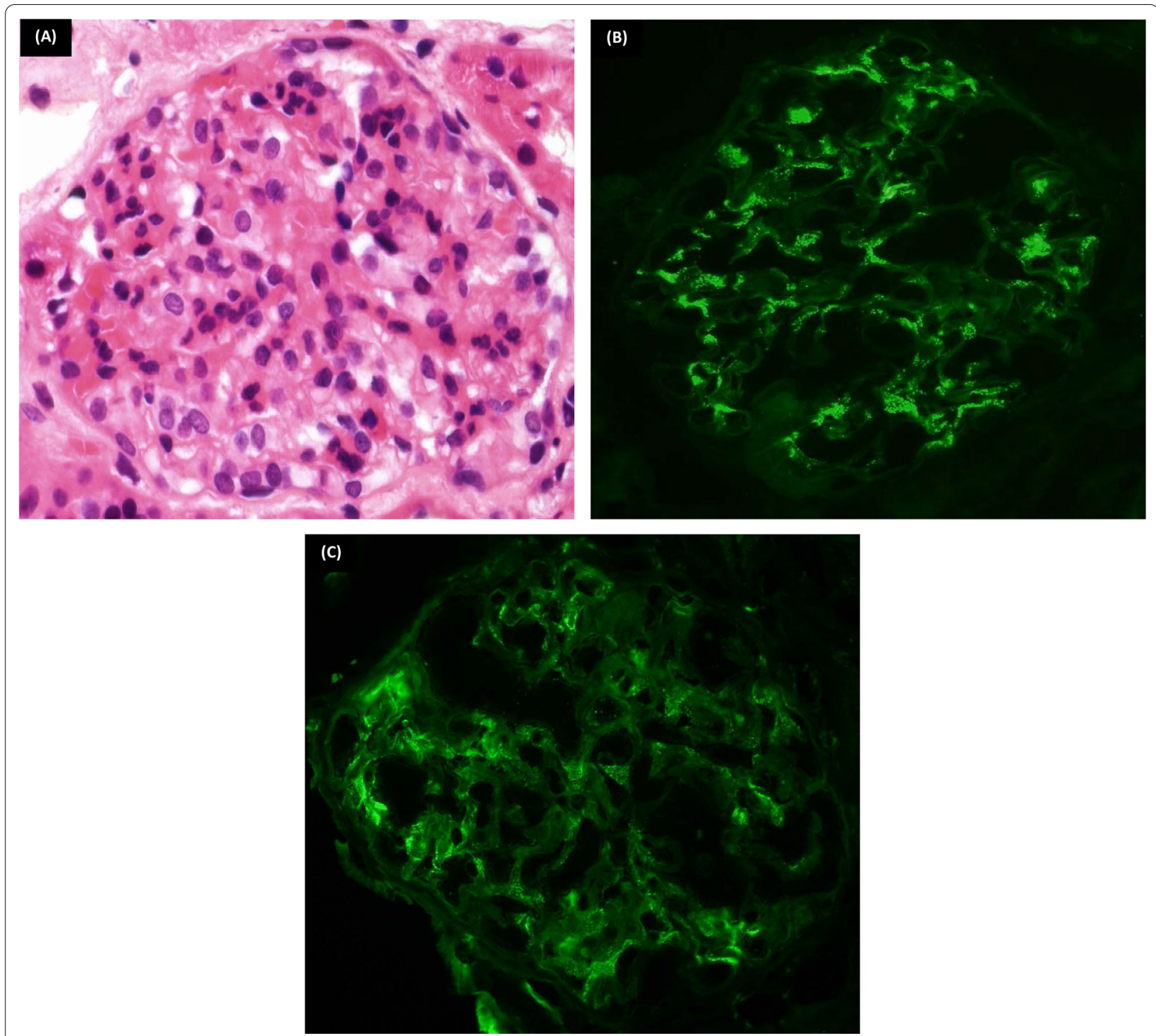

Fig. 1 Glomerular findings (by LM and IF). A [Hematoxylin and eosin (H\&E) × 400]: A glomerulus showing expanded mesangial matrix associated with mesangial hypercellularity. B [Immunofluorescence immunoglobulin G (IF-lgG) × 400]: Positive mesangial granular deposits; score 2. C (IF-IgA $\times 400$ ): Positive mesangial granular deposits; score 1

(Bence Jones) protein/24 hours and clonal bone marrow plasma cells of more than $15 \%$, in addition to presence of anemia with hemoglobin level $9.4 \mathrm{~g} / \mathrm{dL}$ and renal disease manifestations) [1]. The presence of monoclonal marrow plasmacytosis in cases of LCPT is reported in several reports $[12,16,19,20]$, while others are negative for this feature $[14,15,17]$; a variable magnitude of plasma cell recruitment that reflects the diversity of the underlying plasma cell lesions.

SLE has been reported with various forms of plasma cell dyscrasia, including MGUS and amyloidosis.
However, multiple myeloma is very rarely reported with SLE, that is, in just a couple of cases $[9,10]$.

Our case showed two biopsy-proven coincidental lesions: a glomerular lesion consistent with lupus nephritis class II and a tubular lesion of light chain induced tubulopathy that presented in an SLE-known patient without any previously known history of renal involvement. Both lesions are known to be mediated through abnormal activation of immune mechanisms, and although several hypotheses have been raised to explain the activation of monoclonal B cells in SLE patients, whether this 

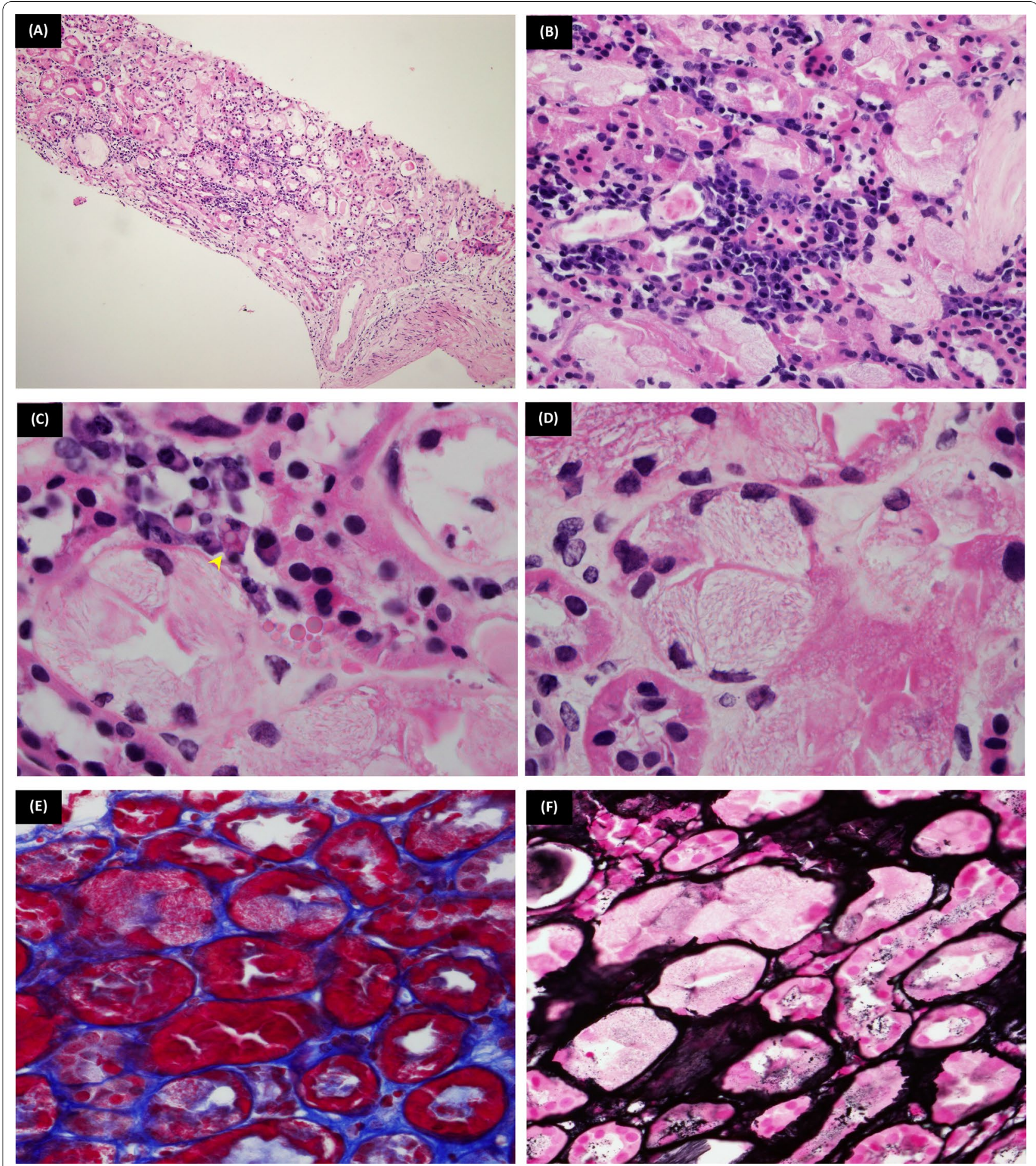

Fig. 2. Proximal tubular lesions. A (H\&E x 100): Renal cortical tissue showing mononuclear (plasmacytic infiltrate) and apparently tubular cytoplasmic inclusions. B (H\&E × 200): The tubular epithelium showing textured intracytoplasmic inclusions. C (H\&E $\times 1000)$ : Monoclonal plasma cells; a Mott cell is seen "arrow head." $\mathbf{D}$ (H\&E × 1000): The proximal tubular epithelium showing textured fibrilloid inclusions of monoclonal light chains. E (Trichrome $\times 400)$, F [Jones' Methenamine Silver $(J M S) \times 400]$ : The tubular inclusions are fuchsinophilic and silver negative 

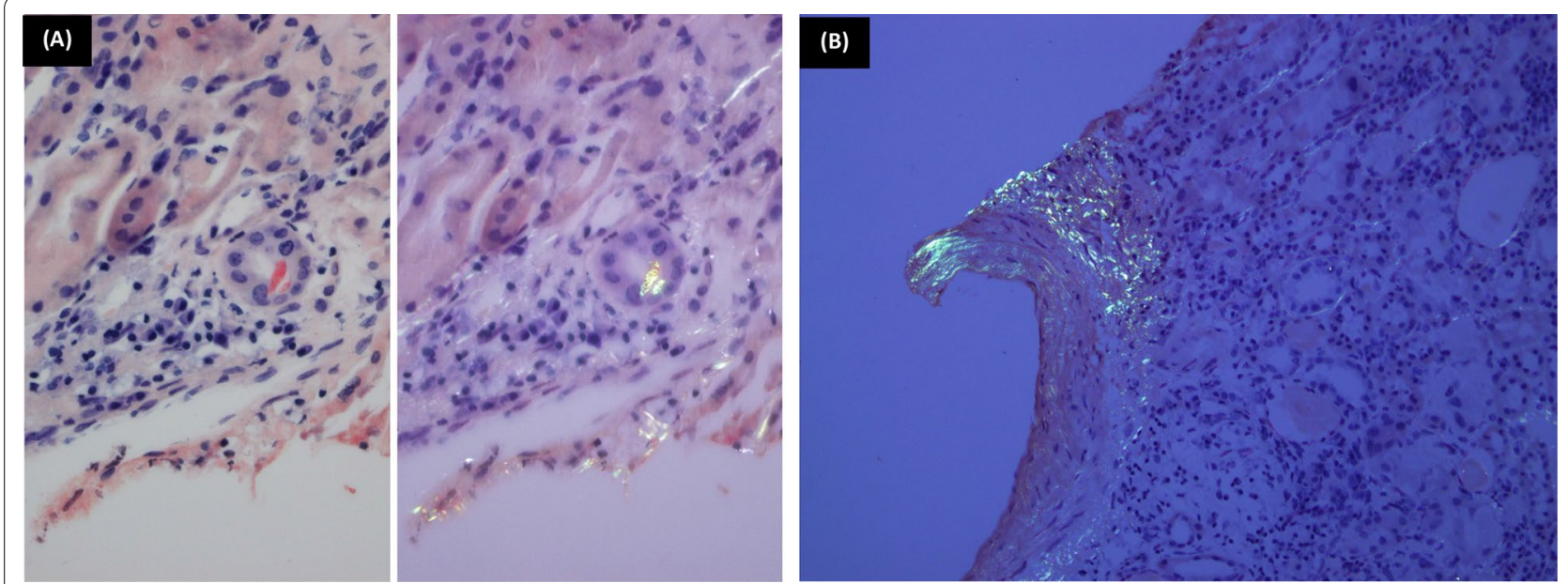

Fig. 3. Amyloidal cast and deposits. A (Congo red $\times 200$ ): Single orangeophilic cast seen giving apple-green birefringence under polarized light. B (Congo red $\times 200$ ): An interlobular sized artery showing amyloidal deposits, as well as the adjacent interstitium
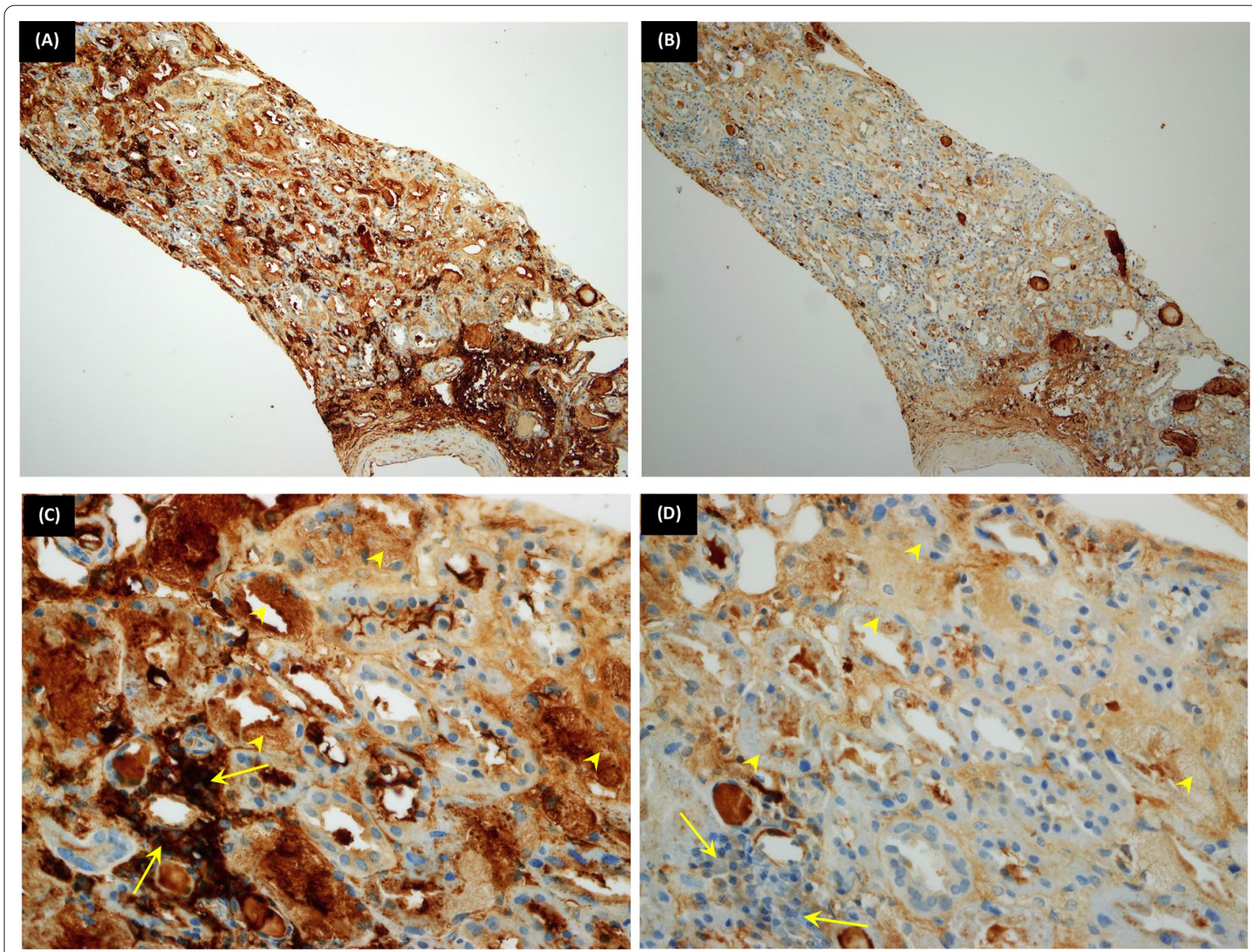

Fig. 4. Immunoperoxidase stains (kappa and lambda); tubular findings. A, B (Immunoperoxidase technique-A: Kappa light chain, B: Lambda light chain $\times 100)$ : The same core as in Fig. 2A; the plasmacytic infiltrate and inclusions showing positivity for kappa light chains rather than lambda. C, D (IP-C: Kappa light chain, D: Lambda light chain $\times 200$ ): The arrowheads are pointing to intratubular cytoplasmic inclusions that are positive for Kappa (Fig. 2C) and negative for Lambda (Fig. 2D). The arrows are pointing to interstitial plasmacytic infiltrate that is also positive for Kappa (Fig. 2C) and negative for Lambda (Fig. 2D) 
Table 3 Serum protein electrophoresis results

\begin{tabular}{llr}
\hline Total protein & $8.8 \mathrm{~g} / \mathrm{dl}$ & $(6.4-8.2 \mathrm{~g} / \mathrm{dl})$ \\
Albumin & $3.4 \mathrm{~g} / \mathrm{dl}$ & $(3.2-5.0 \mathrm{~g} / \mathrm{dl})$ \\
Alpha 1 & $0.2 \mathrm{~g} / \mathrm{dl}$ & $(0.1-0.4 \mathrm{~g} / \mathrm{dl})$ \\
Alpha 2 & $1.2 \mathrm{~g} / \mathrm{dl}$ & $(0.6-1.0 \mathrm{~g} / \mathrm{dl})$ \\
Beta & $1.0 \mathrm{~g} / \mathrm{dl}$ & $(0.6-1.3 \mathrm{~g} / \mathrm{dl})$ \\
Gamma & $3.1 \mathrm{~g} / \mathrm{dl}$ & $(0.7-1.5 \mathrm{~g} / \mathrm{dl})$ \\
Interpretation & Elevated gamma globulin with a spike in the gamma region $(\mathrm{lgG} 3.1 \mathrm{gm} / \mathrm{dl})$ is compatible with monoclonal gam- \\
& mopathy suggests 24-hour urine for Bence Jones protein \\
\hline
\end{tabular}

coincidence has a causal relationship or just a fluke is still unresolved.

\section{Conclusion}

We report a case of coincidental lupus nephritis and proximal tubulopathy featuring a combined constellation of rare histopathological features that might add to the relationship between systemic lupus and paraproteinemia.

\section{Abbreviations}

SLE: Systemic lupus erythematosus; PCD: Plasma cell dyscrasia; LCPT: Light chain proximal tubulopathy; IF: Immunofluorescence; IgG: Immunoglobulin G; IgA: Immunoglobulin A; IgM: Immunoglobulin M; C3: Complement component 3; C1q: Complement component 1q; IP: Immunoperoxidase technique; EM: Electron microscope; MGUS: Monoclonal gammopathy of undetermined significance.

\section{Acknowledgements \\ Not applicable.}

\section{Authors' contributions}

WH and $\mathrm{AE}$ made significant contributions in designing and drafting the manuscript, as well as reviewing the literature, and were involved in the histopathological assessment and diagnosis of the case. Both authors contributed to the manuscript revision and gave final approval for publication. Both authors read and approved the final manuscript.

\section{Funding}

The authors declare that this manuscript was not financially supported.

\section{Availability of data and materials}

All the data utilized in the case report are available from the corresponding author.

\section{Declarations}

Ethics approval and consent to participate: -

Not applicable.

\section{Consent for publication}

Written informed consent was obtained from the patient for publication of this case report and any accompanying images. A copy of the written consent is available for review by the Editor-in-Chief of this journal.

\section{Competing interests}

The authors declare that they have no competing interests.

Received: 23 February 2021 Accepted: 29 June 2021

Published online: 04 August 2021
References

1. Rajkumar SV, Dimopoulos MA, Palumbo A, Blade J, Merlini G, Mateos $M-V$, et al. International Myeloma Working Group updated criteria for the diagnosis of multiple myeloma. Lancet Oncol. 2014;15(12):e538-48.

2. Heher EC, Goes NB, Spitzer TR, Raje NS, Humphreys BD, Anderson KC, et al. Kidney disease associated with plasma cell dyscrasias. Blood. 2010;116(9):1397-404.

3. Herrera GA, Joseph L, Gu X, Hough A, Barlogie B. Renal pathologic spectrum in an autopsy series of patients with plasma cell dyscrasia. Arch Pathol Lab Med. 2004;128(8):875-9.

4. Herrera GA. Renal lesions associated with plasma cell dyscrasias: practical approach to diagnosis, new concepts, and challenges. Arch Pathol Lab Med. 2009;133(2):249-67.

5. Stokes MB, Valeri AM, Herlitz L, Khan AM, Siegel DS, Markowitz GS, et al. Light chain proximal tubulopathy: clinical and pathologic characteristics in the modern treatment era. J Am Soc Nephrol. 2016;27(5):1555-65.

6. Cameron JS. Lupus nephritis. J Am Soc Nephrol. 1999;10(2):413-24.

7. Kraft SW, Schwartz MM, Korbet SM, Lewis EJ. Glomerular podocytopathy in patients with systemic lupus erythematosus. J Am Soc Nephrol. 2004;16(1):175-9.

8. Bajema IM, Wilhelmus S, Alpers CE, Bruijn JA, Colvin RB, Cook HT, et al. Revision of the International Society of Nephrology/Renal Pathology Society classification for lupus nephritis: clarification of definitions, and modified National Institutes of Health activity and chronicity indices. Kidney Int. 2018:93(4):789-96.

9. Ali YM, Urowitz MB, Ibanez D, Gladman DD. Monoclonal gammopathy in systemic lupus erythematosus. Lupus. 2007;16(6):426-9.

10. Maamar M, Tazi Mezalek Z, Harmouche H, Adnaoui M, Aouni M, Maaouni A. Systemic lupus erythematosus and multiple myeloma: an uncommon association. Two cases and literature review. Clin Exp Rheumatol. 2008;26(4):667-70.

11. Shimanovsky A, Alvarez Argote J, Murali S, Dasanu CA. Autoimmune manifestations in patients with multiple myeloma and monoclonal gammopathy of undetermined significance. BBA Clin. 2016;6:12-8.

12. Gowda K, Joshi K, Nada R, Ramachandran R, Sachdeva M. Light chain proximal tubulopathy with cast nephropathy in a case of multiple myeloma. Indian J Nephrol. 2015;25(2):119-22.

13. Yao Y, Wang S-X, Zhang Y-K, Wang Y, Liu L, Liu G. Acquired Fanconi syndrome with proximal tubular cytoplasmic fibrillary inclusions of lambda light chain restriction. Intern Med. 2014;53(2):121-4.

14. Yu X-J, Zhou X-J, Wang S-X, Zhou F-D, Zhao M-H. Monoclonal light chain crystalline podocytopathy and tubulopathy associated with monoclonal gammopathy of renal significance: a case report and literature review. BMC Nephrol. 2018;19(1):322-

15. Patel AB, Choi JY, Mutter WP, Weins A, Riella LV. Crystalline light chain proximal tubulopathy and podocytopathy: a case report. J Bras Nefrol. 2019;42:99-105.

16. Larsen CP, Borrelli GS, Walker PD. Amyloid proximal tubulopathy: a novel form of light chain proximal tubulopathy. Clin Kidney J. 2012;5(2):130-2.

17. Stehlé $T$, Vignon $M$, Flamant $M$, Figueres $M-L$, Rabant $M$, Rodenas $A$, et al. Loss of tubular creatinine secretion as the only sign of tubular proximal cell dysfunction in light chain proximal tubulopathy: a case report. Medicine. 2016;95(26):e3815 
18. Rane S, Rana S, Sachdeva M, Joshi K. Light chain proximal tubulopathy without crystals in a case of Burkitt lymphoma presenting with acute kidney injury. Am J Kidney Dis. 2013;62(3):638-41.

19. Corbett RW, Cook HT, Duncan N, Moss J. Fibrillary inclusions in light chain proximal tubulopathy associated with myeloma. Clin Kidney J. 2012;5(1):75-6.

20. Gallan AJ, Khalighi MA. Lambda light chain crystalline cast nephropathy and proximal tubulopathy. Kidney Int Rep. 2016;1(4):316-20.
21. McKenney JK. Kidney: tumors and tumorlike conditions. In: Goldblum JR, Lamps LW, McKenney JK, Myers JL, eds. Rosai and Ackerman's surgical pathology, Eleventh edn. Elsevier Inc.; 2018. P. 1047.

\section{Publisher's Note}

Springer Nature remains neutral with regard to jurisdictional claims in published maps and institutional affiliations.
Ready to submit your research? Choose BMC and benefit from:

- fast, convenient online submission

- thorough peer review by experienced researchers in your field

- rapid publication on acceptance

- support for research data, including large and complex data types

- gold Open Access which fosters wider collaboration and increased citations

- maximum visibility for your research: over $100 \mathrm{M}$ website views per year

At BMC, research is always in progress.

Learn more biomedcentral.com/submissions 